\title{
ENHANCING COMPETITIVENESS FOR ECONOMIC AND TOURISM GROWTH: CASE OF CROATIA
}

\author{
Adriana Jelušić \\ Karmen Mikulić
}

https://doi.org//10.20867/tosee.06.26

\begin{abstract}
Purpose - the Tourism-Led Economic Growth Hypothesis (TLGH) is fundamental to the development of the tourism countries. The following research stresses the ever-growing importance of knowledge and creativity- through various disciplines - on national competitiveness and overall economic and tourism development. Emphasis will be given to the particulars of the tourism industry, the achieved level of economic growth, the tourism and economic competitiveness as well as the level of creativity. The study asserts that the nation's economic and tourism development corresponds to the acquired competitiveness and creativity level.

Methodology - the relationship between the variables which indicate economic and tourism development, knowledge, competitiveness and creative economy, will be examined through the comparative study on the case of EU countries (EU28). Multiple linear regression model (MLR) is tested on the case of Croatia (IBM SPSS).

Findings - in today's global crisis, one of the ways to promote economic wealth and growth is supporting service and creative industries. Tourism, as a part of the economic growth model, has a strong positive impact on the creative economy and competitiveness. The optimal development model of tourism economies is global comprehensive approach and it encompasses multidisciplinary relationship with all economic activities. Competitiveness, creativity, economic and tourism growth can be used as variables in forecasting tourism demand and tourism consumption.

Contribution - the research's contribution is reflected in a comprehensive study of the competitiveness and creative economy with a particular emphasis on tourism. The proposed macroeconomic model forms an excellent basis for the conduction of an economic policy and the employment of the appropriate instruments.
\end{abstract}

Keywords: international tourism demand, creative economy, economic growth, competitiveness, tourism development, multiple linear regression (MLR).

\section{INTRODUCTION}

Tourism holds a great importance worldwide. In recent decades, the tourism economy, which affects the overall economic growth directly and indirectly, has become increasingly pronounced. On a global scale, tourism is one of the most important economic activities. This is confirmed by the 2019 pre-pandemic year data. Globally, 1 in 10 persons - or every 4th person employed in a new job ( 1 in 4 new jobs) - is employed in the tourism sector. In 2019, the total employment in tourism amounted to $10.6 \%$, the total production amounted to $10.4 \%$ of GDP, the international visitor spending amounted to $6.8 \%$ of global exports and $27.4 \%$ of global service exports (WTTC data). Due to the COVID-19 crisis, the tourism sector suffered an important loss in 2020. According to published data, the decline in tourism production at a global level was $49.1 \%$, while the global economic GDP loss was 3.7\%. Employment in tourism decreased by $18.5 \%$, 
ToSEE - Tourism in Southern and Eastern Europe, Vol. 6, pp. 387-403, 2021.

A. Jelušić, K. Mikulić: ENHANCING COMPETITIVENESS FOR ECONOMIC AND TOURISM ...

domestic tourism consumption decreased by $45 \%$, while foreign tourism consumption, due to restrictions and the inability to travel, decreased by a high $69.4 \%$ (WTTC data). All indicators further highlight the importance of the tourism sector for the overall economy, particularly the importance of foreign tourism for smaller economies. In these economies, foreign tourism revenues represent a significant lever of internal and external economic balance.

Given the smart-inclusive and sustainable growth strategy that the EU has led so far (through the "Europe 2020" strategy) and the fact that we left behind the age of scarcity and entered the era of digital content and culture (UNESCO, 2018), the creative economy and the creative industry have become the heart of a sustainable economy. They are a valuable source for the increase of productivity and wealth, prosperity, and the development in EU countries. Tourism has become the primary economic business dimension for many countries. In fact, many are highly dependent on said industry. Tourism competitiveness is closely linked to the tourist destinations' sustainable development goals, as it provides services that do not have a negative impact on the environment and are based on innovation and resource saving. Since the creative economy concept is not a self-sufficient dimension (Innocenti and Lazzeretti 2019), the interaction with other sectors, (with tourism in this case), results in increased competitiveness, local and regional development, and overall economy health. Every modern economy exhibits a high level of competitiveness in all dimensions, including tourism. The creative industry and tourism are two industries that generate new dimensions and influence creative tourism (OECD 2014) as a specific form of tourism. Creative industry and competitiveness, therefore, are overall indispensable elements of the tourism industry and economy. The purpose of this research is to examine their role and importance, along with the mutual interaction between all elements in achieving faster and stronger economic growth for the EU tourism economies.

The research question is the following: to what extent can international tourism or foreign tourism receipts lead to a faster economic growth in today's competitive global economy? Most of the economic research in this area, known as Tourism-Led Economic Growth Hypothesis (TLGH), confirms the positive relationship between international tourism and economic growth, with the employment of different variables, models, and econometric analysis (Jelušić 2017). In our research, we extend the TLGH by including the criteria of global economic competitiveness, tourism and travel competitiveness along with creativity, and the indicators of economic and tourism development. Extensive investments in knowledge, human resources and technology result in faster growth rates, greater competitiveness, and a higher level of creativity. Can these laws be applied to tourism-receptive economies as well? To what extent can increasing competitiveness and creativity accelerate the growth of tourism countries and the process of competing with the most developed EU countries?

The research question is the following: to what extent can international tourism or foreign tourism receipts lead to a faster economic growth in today's competitive global economy? Most of the economic research in this area, known as Tourism-Led Economic Growth Hypothesis (TLGH), confirms the positive relationship between international tourism and economic growth, with the employment of different variables, models, and econometric analysis (Jelušić 2017). In our research, we extend the TLGH by including 
ToSEE - Tourism in Southern and Eastern Europe, Vol. 6, pp. 387-403, 2021.

A. Jelušić, K. Mikulić: ENHANCING COMPETITIVENESS FOR ECONOMIC AND TOURISM ...

the criteria of global economic competitiveness, tourism and travel competitiveness along with creativity, and the indicators of economic and tourism development. Extensive investments in knowledge, human resources and technology result in faster growth rates, greater competitiveness, and a higher level of creativity. Is there a connection between creativity, knowledge and technology in increasing the competitiveness? Does increasing competitiveness in the economy and tourism lead to improved tourism performance and faster tourism growth?

The work is structured as follows. After the introduction, Section 1 presents the creative economy concept, addressing the main research themes. Section 2 illustrates the research design and methodology of this study. Section 3 presents the comparative study, analyzing the connection between tourism and the overall economic competitiveness among EU countries (EU28). Paper is analyzing tourism industry and tourism development according to the national economic growth in today's competitive global economy. Section 4. as empirical part of the research collect and analyze the available secondary data (for the period between 2007 to 2017) from the global economic competitiveness, tourism competitiveness and creative economy field. Basic aim was in modelling tourism consumption to achieve economic and tourism growth -the case of Croatia. Some final remarks conclude the chapter.

\section{LITERATURE REVIEW}

For decades, tourism has been a significant lever of economic development with a positive impact the population's quality of life. The importance of tourism and tourism consumption has been the subject of numerous studies in recent decades, in a period in which tourism is gaining increasing importance in achieving positive economic and social impacts (Crouch 1995, Peng 2014). Numerous studies have focused their research on the relationship between tourism and economic growth. Balaguer and CantavellaJordá (2002) conducted a systematic study and confirmed the importance of the TLGH theory on the example of Spain. Tourism activity has numerous significant effects on the economy - it is pivotal for its growth, global tourism and development. Several researchers have contributed to the TLGH research, using a variety of variables and several methods. The vast heterogeneity of the research is evident. Nunkoo et al. (2019) presented a meta-regression analysis with 113 studies that tested the TLGH. The research concluded that the results are influenced by a large sensitivity of variables, country specifics, and time spans. They pointed out the need to set more precise research frameworks and add a clearer specification of the obtained results.

In modelling the relationship between tourism and economic growth, different methods and variables were employed. Lim (1997) gave a systematic overview of the methods in forecasting tourism demand as a prerequisite for economic development. The review of the international tourism demand model is based on the systematization of models and methodologies, which depend on explanatory variables. Tourist arrivals and departures along with tourism expenditures and receipts are the most frequently used dependent variables. Income relative tourism prices and transportation costs are the most used explanatory variables. During the 2000s, Lim published several studies, emphasizing the 
ToSEE - Tourism in Southern and Eastern Europe, Vol. 6, pp. 387-403, 2021.

A. Jelušić, K. Mikulić: ENHANCING COMPETITIVENESS FOR ECONOMIC AND TOURISM ...

economic importance of a dynamic approach to international tourism research. On the case of Japan and Australia, she also emphasized the importance of the employment of different econometric models when forecasting the income and production effects of tourism (Lim 2002; 2008).

Within the TLGH research, a significant position is occupied by competitiveness in tourism. Among many researchers, the basic elements were provided by numerous authors (Crouch and Ritchie 1999; Dwyer and Kim 2003; Gomezelj and Mihalič, 2008), who emphasized different elements of comparative and competitive advantages in the models, and directed research towards sustainability, developing or developed countries or small island economies. The approach towards competitiveness research is complex and there is no single optimal model that can be applied to all destinations. In addition, researchers have highlighted the need for greater unity with the competitiveness factor theory (Gomezelj and Mihalič 2008). Ritchie and Crouch $(1999,2005)$ emphasized the importance of furthering tourism expenditure which is the result of increasing the attractiveness of a tourist destination and enhancing the number of satisfied visitors. The latter, through positive economic effects, enables the preservation of natural resources and the destination's overall well-being. Dwyer and Kim (2003) stressed the importance of increasing the living standard of the local population because of tourism destination competitiveness deriving from increased tourism spending. Increased tourism spending is reflected in a higher GDP and improved economic indicators. Ivanov and Webster emphasized the importance of import dependence on tourism and the possibility of increasing foreign tourism consumption along with the consequent reduction of positive economic effects on the economy. This is particularly significant in the globalized business (Ivanov and Webster 2013). In the study of tourism competitiveness, Ivanov and Webster used the World Economic Forum's Travel and Tourism Competitiveness Index (TTCI) for competitiveness and concluded that destination competitiveness does not impact the tourism's influence on economic growth (Ivanov and Webster 2014). The same tourism competitiveness index has been used by other researchers (Kayar and Kozak 2010; Mazanec and Ring 2011).

Technology and knowledge have a positive effect on tourism results and the consequent increase in tourism spending. Garcia Sanchez et al. (2016) researched the connection between tourism competitiveness and innovation on the example of Spain's tourism results. The results of the research stressed specialization as a key factor in competitiveness and highlighted the need to monitor natural and established resources to strengthen competitiveness.

Bucher (2018) conducted a competitiveness study of 41 European countries based on the Global Competitiveness Index (GCI) and used statistical methods to investigate correlations. The research confirmed the high correspondence between GCI as a level of national competitiveness and the human development index, GDP per capita, the level of gender inequality and the travel and tourism industry competitiveness.

Global creativity is closely related to the economic development and growth, competitiveness, and the population's well-being (Florida, Mellander and King 2015). For a long time, it was believed that the value of creative products lies in social, historical, cultural, or symbolic values. The creativity's economic worth was neglected 
ToSEE - Tourism in Southern and Eastern Europe, Vol. 6, pp. 387-403, 2021.

A. Jelušić, K. Mikulić: ENHANCING COMPETITIVENESS FOR ECONOMIC AND TOURISM ...

for years but it acquired importance in the economic policies of the EU at the beginning of the 21 st century. A research today confirms that creativity has a model influence on regional growth and development (Correa et al. 2018). Creativity is primarily connected to art and culture. It generates a new innovative dimension and gives value to the products that nourish a creative economy.

The concept of creative economy is relatively new. There is still no homogenous and standardized definition of creative economy to date. Therefore, the term creative economy is constantly evolving, and this depends on the relationship between human creativity, ideas, intellectual property, knowledge, and technologies. The first mention of the creative industry dates to 1994. It emerged in Australia and then expanded to the UK, where creative industries were defined as "industries which have their origin in individual creativity, skill and talent and which have a potential for wealth and job creation through the generation and exploitation of intellectual property" (DCMS 2001, 5). The European Parliament defined them as "industries that are based on cultural values, cultural diversity, individual and/or collective creativity, skills and talent with the potential to generate innovation, wealth and jobs through the creation of social and economic value, in particular from intellectual property" (EC 2016,10). In 1998, the British Department of Culture Media and Sport first defined the range of activities that form the cultural and creative industries (DCMS 1998) and the creative industry has been observed and researched ever since. Modern research reveals that this is an extremely dynamic sector composed of several subsectors and activities.

Harc et al. (2019) examined the following properties and elements of the creative industry: I) difficult access to financial results due to its non-traditional business model; II) specific forms of creative employment - high percentage of self-employed persons and freelancers; III) Business-to-business (B2B) relationship between clients and customers; IV) specific market conditions - the creative market structure; V) mutual cooperation and business networking among enterprises; VI) the most innovative industry in the economy; cross-sectoral innovation; user-driven innovation; place-bound innovation; VII) internationalization and exports as key elements of a successful creative industry. Due to its complexity, the recent development in the subject field determined new models in measuring the creative industry or the creativity effect. Several composite indicators can analyze the effect of creative indices. Florida's 3 Ts theory inspired the measuring of creativity through a set of indices and in a later stage, the Global Creativity Index (GCI) (Florida, Mellander and King 2015).

\section{RESEARCH METHODOLOGY}

The first step of the empirical part of the research was to collect and analyze the available secondary data from the global economic competitiveness, tourism competitiveness and creative economy field. Given the wide subject matter involving three very dynamic areas - creative industry, tourism and competitiveness, different national approaches and classification standards related to creative economy - data constraint presented a challenge for our study. Descriptive statistics was conducted for examining the relationship between tourism, competitiveness and creative economy variables: a comparative study of European Union (EU 28) economies. Multiple linear regression 
ToSEE - Tourism in Southern and Eastern Europe, Vol. 6, pp. 387-403, 2021.

model (MLR) is tested on the case of Croatia through the Statistical Package for the Social Sciences (IBM SPSS) software.

The World Economic Forum (WEF) has been monitoring the countries' economic competitiveness since 2004. The basic element in the WEF definition is the term productivity. According WEF, productivity means well-being, economic prosperity, economic growth, income growth and an improved life. WEF's methodology related to competitiveness is based on the Global Competitiveness Index (GCI) that has four subindexes and 12 pillars (GCI 4.0): I) enabling environment, II) human capital, III) markets, and IV) an innovative ecosystem.

Tourism competitiveness among EU economies will be argued by using the Travel \& Tourism Competitiveness Index (TTCI). This index measures factors and policies of 136 global countries through four sub-indexes: I) enabling environment; II) travel and tourism policy and enabling conditions; III) infrastructure; and IV) natural and cultural resources (1 to 7 best). Specifically, "natural and cultural resources" can be singled out as indicating one segment of the creative industry related to the creative aspect of competitiveness. We will employ the 5th pillar - higher education and training. This indicator determines the knowledge implementation in global economies when analyzing the creative and transformative economy. This leads to the development and preparation for technological changes. Sub-index $\mathrm{C}$ is entirely focused on the newer areas of competitiveness that concentrate on innovation and new forms of business and management. These are prerequisites for the development of the most advanced economies that achieve the highest GDP per capita and faster economic and tourism growth.

The competitiveness of the EU's creative economy and the concept of creativity will be discussed through the Global Creativity Index (value 0-1 best), as an output for the research by a group of analysts from the Martin Prosperity Institute. Globally studied, 3T - technology, talent, and tolerance - form a single index, the Global Creativity Index that ranks 139 nations worldwide (Florida, Mellander and King 2015).

\section{EXAMINING THE RELATIONSHIP BETWEEN TOURISM, COMPETITIVENESS AND CREATIVE ECONOMY VARIABLES: A COMPARATIVE STUDY}

Tourism development is an important element for the overall economy and competitiveness among global economies, especially for those in which tourism presents a significant lever. This is characteristic to all Mediterranean countries in the EU, especially those with less consumer market power. The shift of tourist arrivals per capita in EU countries for 2019 (graph 1), shows that small EU tourism economies are among the leading destinations: Croatia and Malta have more than 4 arrivals per capita, Greece and Cyprus are in the group of 3 arrivals per capita, while Spain, Portugal, France, and Italy are in the group of 2 arrivals per capita. Using available secondary data, we can assume that foreign tourist consumption (inbound tourism receipts) is positively correlated with tourism arrivals per capita and follow similar trend. 
ToSEE - Tourism in Southern and Eastern Europe, Vol. 6, pp. 387-403, 2021.

Graph 1: Arrivals per capita in EU, 2019

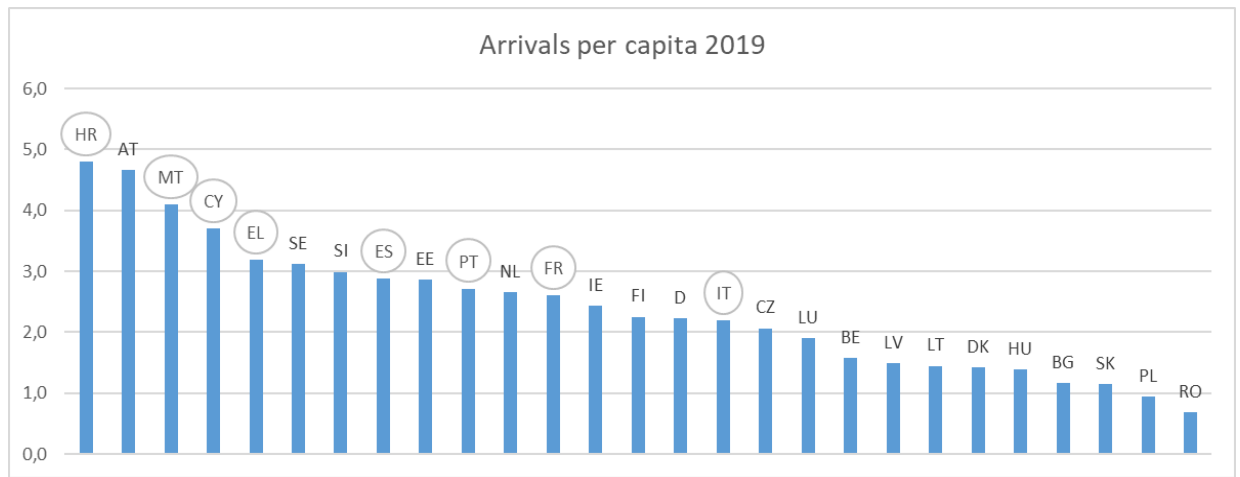

Source: own processing based on EUROSTAT data

Luxembourg takes the leading position in travel balance per capita for 2019 (graph 2). Due to its specific size and economy, this country will be excluded from a more detailed analysis. The Mediterranean EU countries that achieve a travel balance surplus are also the countries that are leading with the number of arrivals per capita; largest surpluses per capita were achieved by smaller tourism countries such as Malta, Croatia, Cyprus, and Greece, followed by larger tourism destinations. Leading outbound tourism economies have the largest deficits in travel balance per capita with the leading countries being Belgium, Germany, Sweden, Finland, Ireland, and the UK. In conclusion, the leading outbound tourism economies are experiencing a deficit of the travel balance, primarily due to a high percentage of tourist-spending abroad and consequentially, increasing outbound travel expenditures. On the other hand, inbound tourism economies achieve a surplus in travel balance mainly because of the low value of domestic tourism expenditures in addition to the high and rising value of foreign tourism receipts.

\section{Graph 2: Travel balance per capita in EU, 2019 (EUR)}

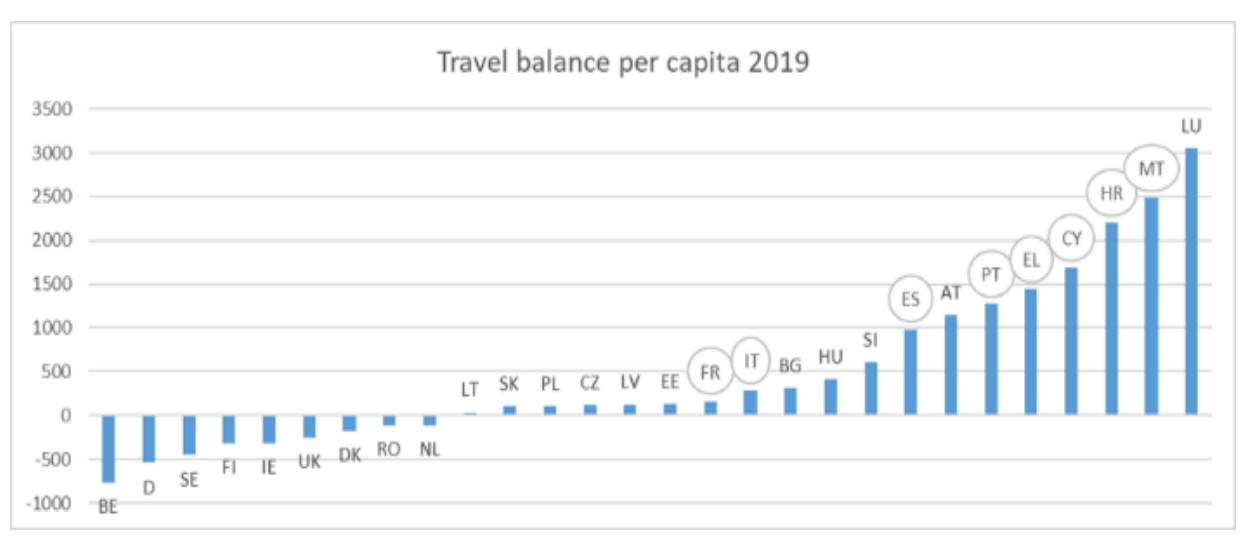

Source: own processing based on EUROSTAT data 
ToSEE - Tourism in Southern and Eastern Europe, Vol. 6, pp. 387-403, 2021.

A. Jelušić, K. Mikulić: ENHANCING COMPETITIVENESS FOR ECONOMIC AND TOURISM ...

However, the Mediterranean EU economies including Croatia have not achieved the average level of economic development (graph 3). The picture of economic development is mirrored in tourism indicators. Leading outbound tourism economies achieved the highest GDP per capita in 2019. Mediterranean tourism economies with their GDP per capita between 30000-40000 EUR are France, Italy, and Malta; the group of countries with 20000-30000 EUR includes Spain, Cyprus, and Portugal; the lowest values between 10000-20000 EUR are achieved by Greece and Croatia.

Graph 3: GDP per capita in EU, 2019 (EUR)

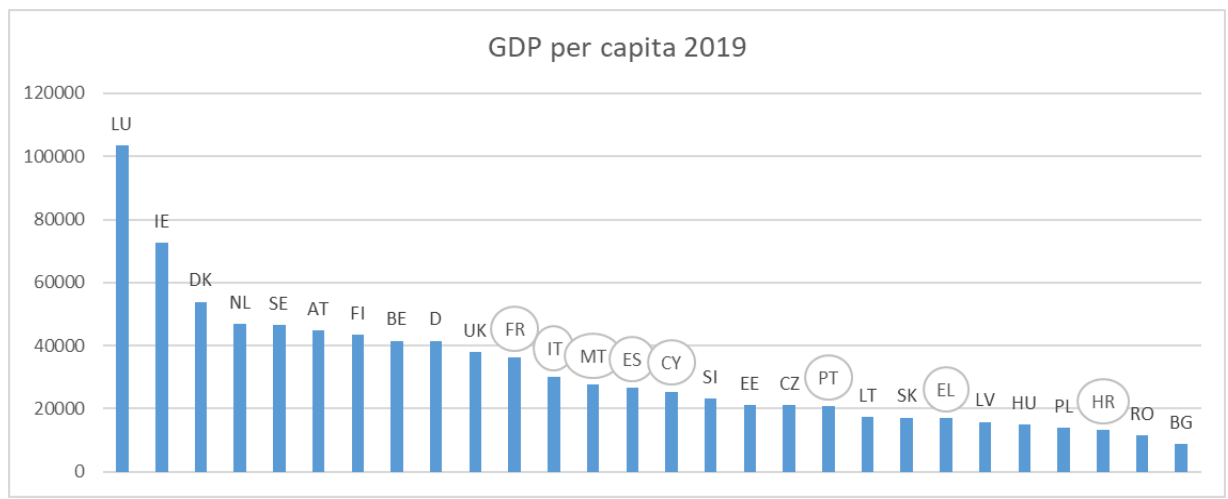

Source: own processing based on the EUROSTAT data

Australia has the best ranking on the Global Creativity Index (graph 4). In previous surveys (2004 and 2011), Sweden ranked best and took the lead. It was followed by the United States, New Zealand, Canada, Denmark, Finland, Sweden, Iceland, Singapore, and the Netherlands. Several EU countries are among the top 10. According to the Global Creativity Index, which shows economic development and implementation of the creative economy through the talent, tolerance and technology dimension, there is high correlation with the GDP per capita. Therefore, following graph 4, we can conclude that the highest values of the Global Creativity Index were achieved by Denmark, Finland, and Sweden (0.9), with a possible value of $0-1$ best. Observing the geographical dispersion, a high level of creativity is achieved by Scandinavian countries, the middle level is achieved by Central and Eastern European countries, and the lowest values are achieved by countries with the largest deviations from the average economic development of the EU including small Mediterranean tourism economies. Croatia and Cyprus are ranked with a low value of the Global Creativity Index (below 0.5). 
ToSEE - Tourism in Southern and Eastern Europe, Vol. 6, pp. 387-403, 2021.

\section{Graph 4: Global Creativity Index 2015 in EU}

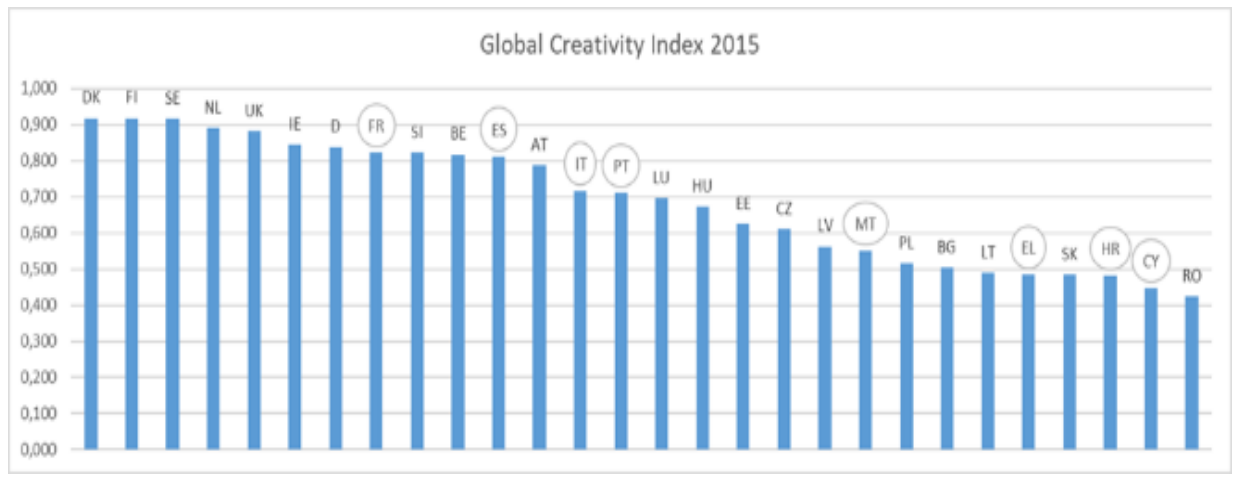

Source: own processing based on the Florida et.al (2015)

The next research question relates to the inter-connection between creativity (creative industry) and tourism competitiveness. The reciprocity between the creative industry and tourism competitiveness is shown in the following matrix - graph 5. The Global Creativity Index of all EU economies is higher than 0.4. The highest value above 0.9 is achieved by Denmark, Sweden, and Finland. Considering tourism competitiveness (TTCI), Denmark holds the best position. According to the tourism competitiveness indicator and the creative industry, the UK, Germany, France, and Spain are highly ranked. Mediterranean economies with the highest level of economic growth and tourism results hold the best position. In addition, we can assume that they have the highest level of creativity in the creative tourism area, which creates a further premise for economic and tourism development. The Central European economies form the middle group of countries, while the smaller Mediterranean tourism economies are placed in the lower left part of the matrix (Croatia included). In these economies, creativity has the lowest rank in the EU, which also means they lag in tourism competitiveness.

Graph 5: Global Creativity Index vs. TTCI 2019

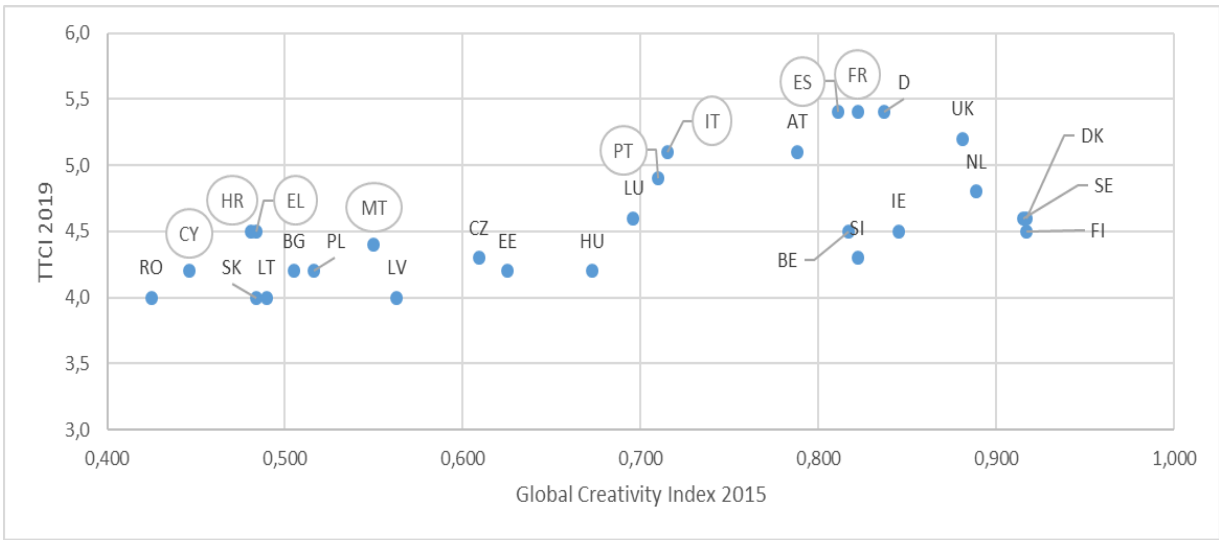

Source: own processing based on the Florida et.al (2015); WTTC.org 
ToSEE - Tourism in Southern and Eastern Europe, Vol. 6, pp. 387-403, 2021.

A. Jelušić, K. Mikulić: ENHANCING COMPETITIVENESS FOR ECONOMIC AND TOURISM ...

The connection between tourism and the overall economic competitiveness will be further analyzed by using the Global Competitiveness Index (GCI) as a basic indicator for their mutual connection. The matrix shows (graph 6) the grouping of the EU economies according to the economic development and tourism indicators. The most developed economies are positioned in the upper right, forming the group of the most competitive economies that achieve excellent tourism indicators. These are the leading tourist destinations: France, Spain, Italy, but also the leading European outbound tourism economies: Croatia, Germany, UK and Austria. In the most competitive economies group, we can find also the Scandinavian countries. Competitive group is formed by the central and eastern European economies and the less competitive group with small EU Mediterranean economies. We can assume that increasing creativity and implementing the legality of the creative industry in the economy and tourism, will increase global competitiveness and improve economic and tourism achievements.

\section{Graph 6: TTCI vs. GCI 2017-2018 for EU}

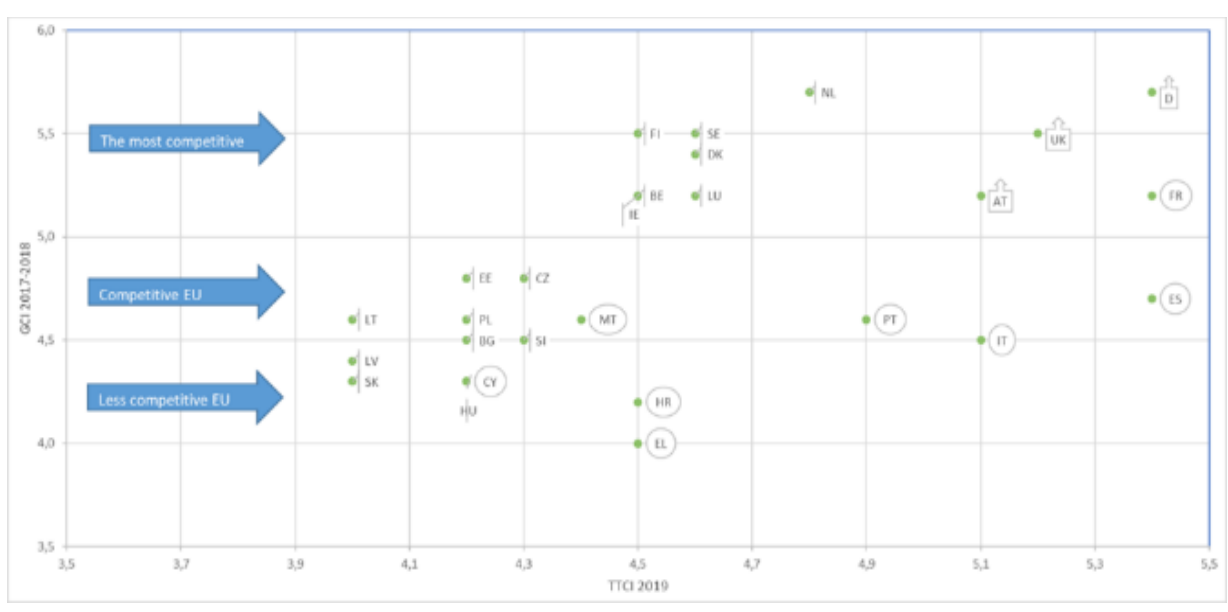

Source: own processing based on the World Economic Forum data; WTTC.org

The GDP per capita matrix as an indicator of economic development and the Global Creativity Index, as a development of the creative industry indicator (graph 7), are correlated. The EU economies are grouped and distributed regionally and by their development. The most economically developed countries constitute the first group. Those countries have a higher level of creativity. The second group, which encompasses Mediterranean EU economies (including Croatia) is positioned in the lower left part of the matrix. 
ToSEE - Tourism in Southern and Eastern Europe, Vol. 6, pp. 387-403, 2021.

\section{Graph 7: GDP per capita 2019 vs. Global Creativity Index 2015}

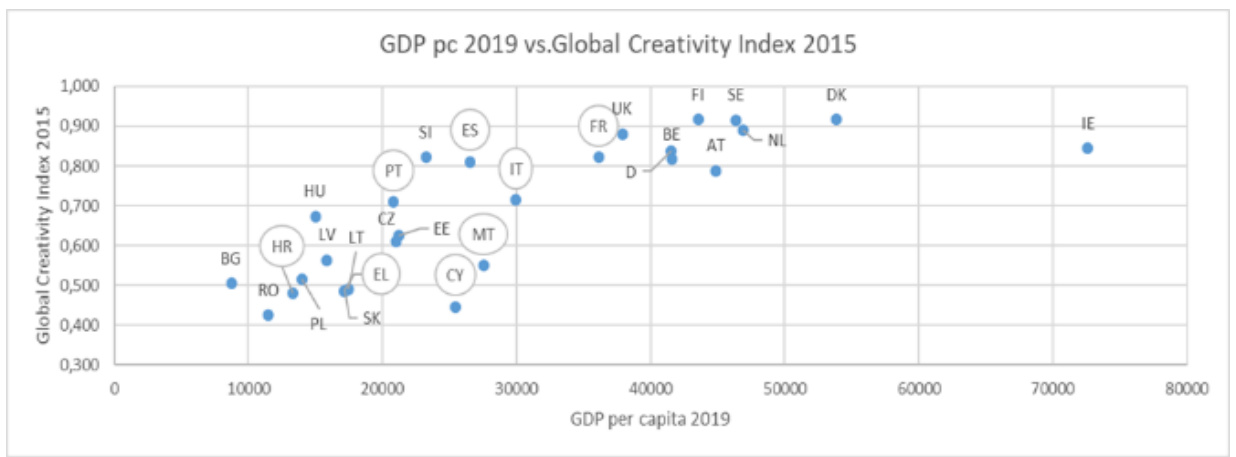

Source: own processing based on the EUROSTAT data; Florida et.al (2015)

The observation of the economic development movement, the GDP per capita, and tourism competitiveness are of great interest to our research. The following matrix (graph 8 ) shows the division of countries into two groups: the most economically developed economies with a higher level of creativity, have also show the best results in the tourism competitiveness group. A similar conclusion can be drawn for the small Mediterranean tourism economies group.

\section{Graph 8: GDP pe vs TTCI 2019}

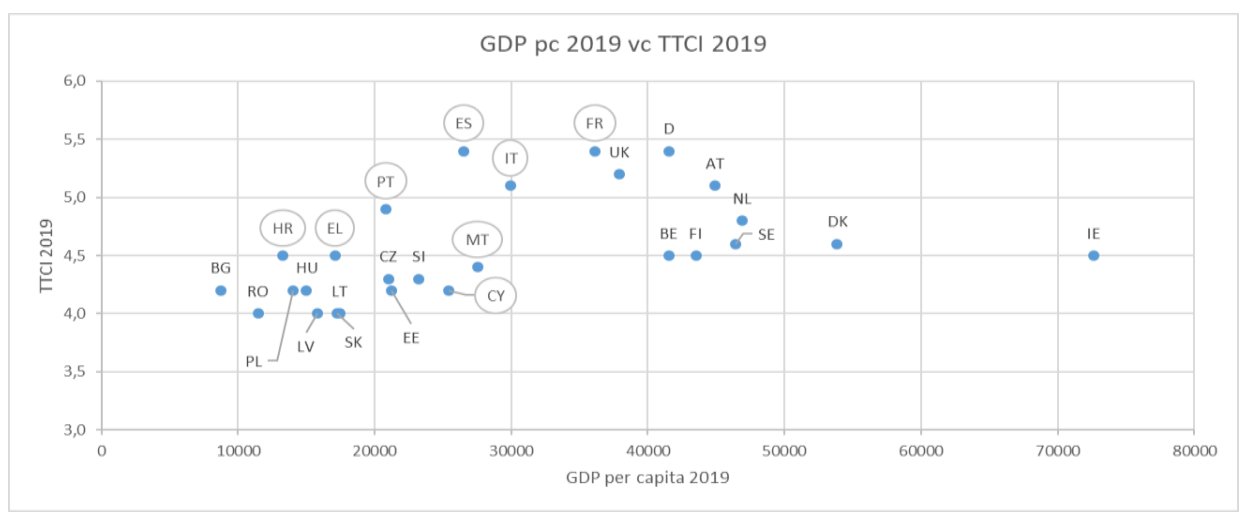

Source: own processing based on the EUROSTAT data, WTTC.org

Having mentioned all the above, we can assume that global competitiveness is positively related to the degree of economic development. The latter is positively correlated with the development of creativity, creative industries, and consequently creative tourism. Higher creativity levels are beneficial to the development of a creative industry, creative tourism, and the economic development between EU economies. We can moreover assume that the less developed EU Mediterranean economies will accelerate their economic and tourism development by implementing new creative industry models and solutions in all economic activities including tourism. 
ToSEE - Tourism in Southern and Eastern Europe, Vol. 6, pp. 387-403, 2021.

A. Jelušić, K. Mikulić: ENHANCING COMPETITIVENESS FOR ECONOMIC AND TOURISM ...

\section{MODELLING TOURISM CONSUMPTION TO ACHIEVE ECONOMIC AND TOURISM GROWTH: CASE OF CROATIA}

In the present study, the following demand function portrays the international tourism consumption or the international tourism receipts (inflows):

$$
\text { TRAVEL_CREDIT } T_{I}=a * A R R I V A L S_{i}^{b 1} * G D P_{i}^{b 2} * G C I_{i}^{b 3} * G C I 5_{i}^{b 4} * \varepsilon_{i}
$$

Where:

TRAVEL_CREDITi is the proxy for international tourism receipts in a tourism economy.

ARRIVALSi is the number of foreign tourism arrivals in tourism country, and it is a proxy for tourism development.

GDPi is the gross domestic product data for the tourism economy, and it acts as a proxy for the level of economic development.

GCli is the global competitiveness index (the overall value) for the tourism economy, and it acts as a proxy for the competitiveness level.

GCI5i is the global competitiveness index's 5th pillar, regarding the tourism economy and acts as a proxy for the knowledge and competitiveness level in the knowledge field.

According to Song and Witt (2000), the model of international tourist expenditures can be transformed into a log-linear model. It can then be estimated using the ordinary least squares (OLS) model.

InTRAVEL_CREDIT

$$
=\ln a+b_{1} \ln A R R I V A L S_{i}+b_{2} \ln G D P_{i}+b_{3} \ln G C I_{i}+b_{4} \operatorname{lnGCI}_{i}+\varepsilon_{i}
$$

The international tourism consumption can be expressed in a functional form as TRAVEL_CREDIT $=\mathrm{f}$ (ARRIVALS, GDP, GCI, GCI5), with the addition of further assumptions: an increase in the international tourist arrivals leads to the increase in international tourism receipts (credit); the economic growth and GDP increase in a tourism economy is a positive precondition and it leads to the growth of international tourism receipts; the increase in creativity and knowledge level to international tourism consumption growth. The growth of the knowledge level is positively connected to the technology implementation and it will further attract higher-spending tourists, which results in a growth of international tourism receipt levels.

The initial model is tested on Croatia's economy. The empirical analysis is carried out using a set of annual data from 2007 to 2017 (as the available data for all variables included in the model is limited, data from this time span will be used). Research methodology is based on the available secondary data. The correlation matrix shows the correspondence between the dependent variable (InTRAVEL_CREDIT) and each independent variable, as well as the correspondence between independent variables. 
ToSEE - Tourism in Southern and Eastern Europe, Vol. 6, pp. 387-403, 2021.

A. Jelušić, K. Mikulić: ENHANCING COMPETITIVENESS FOR ECONOMIC AND TOURISM ...

Table 1: The correlation matrix - Pearson Correlation

\begin{tabular}{lc}
\hline Correlation TRAVEL_CREDIT & Pearson Correlation \\
\hline $\ln$ ARRIVALS & 0,860 \\
$\operatorname{lnGDP}$ & 0,622 \\
$\operatorname{lnGCI}$ & 0,548 \\
$\operatorname{lnGCI5}$ & 0,662 \\
\hline
\end{tabular}

Source: Research results

The summary output including all independent variables is shown in the following table. As seen in the model, $97 \%$ of the total international tourism consumption variation is explained by four predictor variables: ARRIVALS, GDP, GCI and GCI5. A high value for R2 and the adjusted R2 value (0.970) appear to suggest that the model fits the data well. The regression coefficients in log-linear form indicate that a $1 \%$ change in the international tourist arrivals in Croatia, keeping all other conditions unchanged, will increase foreign tourist consumption by $0.35 \%$. All variables have the expected signs and the regression coefficients indicating that each variable is strongly responsible for international tourism consumption and tourism growth. The model's results show that the accumulation of economic development and the increased competitiveness will have the greatest impact on tourism growth.

Table 2: Empirical results of modelling Croatia's international tourism consumption using the MLR model - first step

\begin{tabular}{lrrr}
\hline Variable & Coefficients & Std.Error & t-value \\
\hline Constant & $-14,180$ & 4,613 & $-3,074$ \\
lnARRIVALS & 0,359 & 0,122 & 2,949 \\
lnGDP & 1,309 & 0,505 & 2,594 \\
lnGCI & 1,906 & 1,071 & 1,780 \\
lnGCI5 & 0,276 & 0,933 & 0,296 \\
\hline Tests & & & \\
$\mathrm{R}^{2}=0,970$ & Adj. $\mathrm{R}^{2}=0,900$ & $\mathrm{~F}=23,555$ & $\mathrm{~d}=1,646$ \\
\hline
\end{tabular}

Source: Research results

The analysis of t-values reveals that all individual variables are statistically different from 0 . A more detailed analysis of the t-test indicates the need to additionally observe the GCI and GCI5 variables from the model, as these variables are not statistically important at 5\% significance level. The lowest results are shown by the creative economy and knowledge variable GCI5. Another iteration of the model will be made without this variable. Regarding the strength of the model, the F-statistics reject the null-hypothesis that all coefficients are jointly zero at $1 \%$ significance level. This indicates that all explanatory variables are important and independent in explaining international tourism receipts.

The next step in the modelling procedure is presented by a second step model in a potential and log-linear form: 
ToSEE - Tourism in Southern and Eastern Europe, Vol. 6, pp. 387-403, 2021.

$\operatorname{lnTRAVEL} L_{-} C R E D I T_{I}=\ln a+b_{1} \ln A R R I V A L S_{i}+b_{2} \ln G D P_{i}+b_{3} \ln G C I_{i}+\varepsilon_{i}$

The results of the multiple linear regression modelling are shown in table 3 below. According to this model, three predictor variables justify the $96.9 \%$ of the total variation in international tourism receipts: ARRIVALS, GDP and GCI. The model fits the data better. All variables have the expected signs and regression coefficients, indicating that each variable is strongly responsible for the international tourism receipts (inflows). The $\mathrm{t}$-values analysis reveals that all individual variables are statistically different than 0 and can be employed in this model. The GCI competitiveness variable has the weakest significance, and it can be accepted with a $91 \%$ significance. Regarding the strength of the model, the F-statistics reject the null hypothesis that all coefficients are jointly zero at a $1 \%$ significance level, indicating that all explanatory variables are important and independent in explaining foreign tourism receipts. The F-test value is 36.081 and it rejects the null hypothesis with a $99 \%$ significance.

Table 3: Empirical results of modelling Croatia's international tourism consumption using the MLR model - second step

\begin{tabular}{llll}
\hline Variable & Coefficients & Std.Error & t-value \\
\hline Constant & -13.582 & 3.869 & -3.511 \\
$\ln$ ARRIVALS & 0.390 & 0.053 & 7.381 \\
$\operatorname{lnGDP}$ & 1.237 & 0.411 & 3.007 \\
$\operatorname{lnGCI}$ & 1.962 & 0.983 & 1.995 \\
\hline Tests & & & \\
$\mathrm{R}^{2}=0.969$ & Adj. $\mathrm{R}^{2}=0.913$ & $\mathrm{~F}=36.081$ & $\mathrm{~d}=1.585$ \\
\hline
\end{tabular}

Source: Research results

The test of collinearity (VIF test) has a satisfactory value from 1.098 to 1.347 , which means that there is no collinearity between predictor variables. The Durbin-Watson test for autocorrelation has a possible range of 0 to 4 . In our model it is 1.585 . We can confirm that there is no autocorrelation present in error terms. The analysis of t-values reveals that all individual variables are statistically different from 0 and can be used in this model. The F-statistics rejects the null hypothesis that all coefficients are jointly zero at a $1 \%$ significance level. This indicates that all explanatory variables are crucial and independent in explaining international tourist expenditures.

\section{CONCLUSIVE REMARKS AND FURTHER RESEARCH}

Tourism, as a part of the TLHG and economic growth model, has a strong positive impact on economic growth. Tourism development is an important element for the overall economy and competitiveness among global economies, especially for those in which tourism presents a significant lever. We broadened the TLGH literature by investigating the creativity and competitiveness which is fundamental to the correlation between tourism and economic growth. This research highlights the importance of the tourism sector for the overall economy, particularly the importance of foreign tourism for smaller 
ToSEE - Tourism in Southern and Eastern Europe, Vol. 6, pp. 387-403, 2021.

A. Jelušić, K. Mikulić: ENHANCING COMPETITIVENESS FOR ECONOMIC AND TOURISM ...

economies. In these economies, foreign tourism receipts are crucial for internal and external economic balance.

Our findings suggest that countries with a higher level of economic development (GDP per capita) have a higher level of overall economic competitiveness (GCI). Countries with a surplus in travel balance whose economy is highly dependent on foreign tourism inflows, achieve a higher level of tourism competitiveness. This hypothesis needs broader investigation since Mediterranean EU countries show a significant correlation with the level of economic development. Countries that achieve a higher level of economic competitiveness (GCI) also achieve a higher level of competitiveness in the tourism sector, i.e., they have a higher Tourism and Travel Competitiveness Index (TTCI). Countries that achieve higher rates of economic development have a higher level of global creativity, which is expressed by the Global Creativity Index. Mediterranean EU countries highly depend on foreign tourism inflows and need to speed up a process economic growth through the development of creative industries and creative tourism.

The research suggests the applicability of economic and tourism data, as well as data on global competitiveness for modelling foreign tourist receipts. Available secondary data on the creative economy are monitored at a general level. For the purposes of researching creative tourism and the role of the creative economy in tourism, it is extremely important to improve the monitoring and presentation of data on the role of creative tourism for tourism and general economic growth. Assuming our findings are valid, a further implication is the need for more exact and detailed understanding of how tourism could best support and be supported by the creative industry. The employment of knowledge and creativity will accelerate a sustainable economy and tourism, in addition to the overall visibility of the country's tourism on the global market.

Subject research conducted on the example of Croatia and EU countries opens the possibility of research through a panel regression model and other econometric methods. Compared to previous research, this research is an excellent starting point for including additional variables in forecasting tourism and economic results. The introduction of additional variables representing the tourism and economic level of development at the technology, competitiveness and creativity level would increase the applicability of the model for economic and tourism policy makers. On the other hand, the importance of the continuous need to invest in the innovation of the tourist product would be further emphasized. This paper represents the foundations for further research and has significant application opportunities. The need to monitor the creative industry and creative tourism with the lack of an internationally comparable and harmonized methodology was especially emphasized. This opens the need for further research, especially in the field of creative industry. Pandemic conditions raise additional questions of impact on competitiveness, creativity and innovation in the function of normalizing tourism trends in the future. 
ToSEE - Tourism in Southern and Eastern Europe, Vol. 6, pp. 387-403, 2021.

A. Jelušić, K. Mikulić: ENHANCING COMPETITIVENESS FOR ECONOMIC AND TOURISM ...

\section{REFERENCES}

Balaguer, J., Cantavella-Jordá, M. (2002), "Tourism as a long run economic growth factor: the Spanish case", Applied Economics, Vol. 34, No. 7, pp. 877-884. doi: 10.1080/00036840110058923

Bucher, S. (2018), "The Global Competitiveness Index as an Indicator of Sustainable Development", Herald of the Russian Academy of Science, Vol. 88, No. 1, pp. 44-57. doi: 10.1134/S1019331618010082

Correa-Quezada, R., Álvarez-García, J., Del Río-Rama, M.D.C. and Maldonado-Erazo, C.P. (2018), "Role of Creative Industries as a Regional Growth Factor", Sustainability, Vol. 10, No. 5, 1649. doi: $10.3390 / \mathrm{su} 10051649$

Crouch, G.I. (1995), “A meta-analysis of tourism demand”, Annals of Tourism Research, Vol. 22, No. 1, pp. 103-118. doi: 10.1016/0160-7389(94)000054-V

Crouch, G. I. and Ritchie, J.R.B. (1999), "Tourism, competitiveness, and societal prosperity", Journal of Business Research, Vol. 44, No. 3, pp. 137-152. doi: 10.1016/S0148-2963(97)00196-3

Department of Culture Media and Sport (United Kingdom) (1998), Creative industries mapping document 1998, DCMS, London.

Department of Culture Media and Sport (United Kingdom) (2001) The creative industries mapping document 2001, DCMS, London.

Dwyer, L. and Kim, C. (2003), "Destination competitiveness: determinants and indicators", Current Issues in Tourism, Vol. 6, No. 5, pp. 369-414. doi: 10.1080/13683500308667962

European Commission [EC] (2016), Boosting the competitiveness of the cultural and creative industries for growth and jobs. European Commission, Brussels, https://ec.europa.eu/growth/content/boostingcompetitiveness-cultural-and-creative-industries-growth-and-jobs-0_en

EUROSTAT database, https://ec.europa.eu/eurostat/web/tourism/data/database

Florida, R., Mellander, C., and King, K. (2015), The global creativity index 2015, Martin Prosperity Institute.

García Sánchez, A., Siles López, D., Artal-Tur, A. and Kozak, M. (2016), "Tourism destination competitiveness and innovation: the case of the Spanish Mediterranean coast", in Destination competitiveness, the environment and sustainability: challenges and cases, pp. 13-23.

Gomezelj Omerzel, D. and Mihalič, T. (2008), "Destination Competitiveness- Applying Diffrenent Models: The Case of Slovenia", Tourism Management, Vol. 29, No. 2, pp. 294-307. doi: 10.1016/j.tourman.2007.03.009

Harc, M., Bestvina Bukvić, I. and Mijoč, J. (2019), "Entrepreneurial and Innovative Potential of the Creative Industry”, in Barković, D., Crnković, B., Zekić Sušac, M., Dernoscheg, K., Pap, N., Runzheimer, B. and Wentzel, D. (Eds.) Interdisciplinary Management Research XV.

Ivanov, S. and Webster, C. (2013), "Globalisation as a driver of destination competitiveness", Annals of Tourism Research, No. 43, pp. 628-633.

Ivanov, S. and Webster, C. (2014), "Transforming competitiveness into economic benefits: Does tourism stimulate economic growth in more competitive destinations?”, Tourism Management, Vol. 40, pp. 137-140. doi: 10.1016/j.tourman.2013.06.003

Jelušić, A. (2017), "Modelling tourist consumption to achieve economic growth and external balance: case of Croatia", Tourism and hospitality management, Vol. 23, No. 1, pp. 87-104. doi: 10.20867/thm.23.1.5

Kayar, C.H. and Kozak, N. (2010), "Measuring destination competitiveness: an application of the travel and tourism competitiveness indeks", Journal of Hospitality Marketing and Management, Vol. 19, No. 3, pp. 203-216. doi: 10.1080/19368621003591319

Lim C. and McAller M. (2002), "Time series forecasts of international travel demand for Australia", Tourism Management, Vol. 23, No. 4, pp. 389-396. doi: 10.1016/S0261-5177(01)00098-X

Lim C., Min, J.C.H. and McAleer, M. (2008), "Modelling income effects on long and short haul international travel from Japan, Tourism Management", Vol. 29, No. 6, pp. 1099-1109. doi: 10.1016/jtourman.2008.02.012.

Lim, C. (1997), "Review of international tourism demand models", Annals of Tourism Research, Vol. 24, No. 4, pp. 835-849. doi: 10.1016/S0160-7383(97)00049-2

Mazanec, J. A. and Ring, A. (2011), "Tourism destination competitiveness: second thoughts on the World Economic Forum reports", Tourism Economics, Vol. 17, No. 4, pp. 725-751. doi: $10.5367 /$ te. 2011.0065

Innocenti, N. and Lazzeretti, L. (2019), "Do the creative industries support growth and innovation in the wider economy? Industry relatedness and employment growth in Italy," Industry and Innovation, Vol. 26, No. 10, pp. 1152-1173. https://doi.org/10.1080/13662716.2018.1561360

Nunkoo, R., Seetanah, B. and Khan Jaffur, Z.R. (2019), “Tourism and Economic Growth: A Meta-regression Analysis", Journal of Travel Research, Vol. 59, No. 3, pp. 404-423. doi: $10.1177 / 0047287519844833$ 
ToSEE - Tourism in Southern and Eastern Europe, Vol. 6, pp. 387-403, 2021.

A. Jelušić, K. Mikulić: ENHANCING COMPETITIVENESS FOR ECONOMIC AND TOURISM ...

OECD (2014), Tourism and the Creative Economy, OECD Studies on Tourism, OECD Publishing, Paris. doi: 10.1787/9789264207875-en

Peng, B., Song, H. and Crouch, G.I. (2014), “A meta-analysis of international tourism demand forecasting and implications for practice", Tourism Management, Vol. 45, pp. 181-193. doi: 10.1016/j.tourman.2014.04.005

Ritchie, J.R.B. and Crouch, G.I. (2005), The competitive destination: A sustainable tourism perspective, Oxford University Press, Oxford.

Song, H. and Witt, S.F. (2000), Tourism Demand Modelling and Forecasting: Modern Econometric Approaches, Elsevier, Oxford.

UNCTAD (2018), Creative economy outlook: Trends in international trade in creative industries 2002-2015, Country Profiles: 2005-2014, in United Nations Conference on Trade and Development.

World Economic Forum database, https://reports.weforum.org/travel-and-tourism-competitiveness-report2019/country-profiles

WTTC database, https://Research/Economic-Impact

\section{Adriana Jelušić,}

University of Rijeka

Faculty of Tourism and Hospitality Management, Opatija

Primorska 46, P.O.Box 97, 51410 Opatija, Croatia

+38551294758

adrianas@fthm.hr

Karmen Mikulić,

University of Rijeka

Faculty of Tourism and Hospitality Management, Opatija

Primorska 46, P.O.Box 97, 51410 Opatija, Croatia

+38551294680

karmenm@fthm.hr 